OnLine Journal of Biological Sciences 7 (1): 30-43, 2007

ISSN 1608-4217

(C) 2007 Science Publications

\title{
Uptake and Translocation of Manganese by Native Tree Species in a Constructed Wetland Treating Landfill Leachates
}

\author{
A. Snow and A.E. Ghaly \\ Department of Process Engineering and Applied Science, Dalhousie University, \\ Halifax, Nova Scotia, Canada
}

\begin{abstract}
A surface flow constructed wetland was used to treat stormwater runoff from surrounding watersheds which are comprised primarily of commercial properties and two former landfills. The uptake of manganese by red maple, white birch and red spruce trees growing under flooded soil conditions in the constructed wetland was compared to that of the same trees growing under well drained soil conditions in a nearby reference site. The seasonal variability of manganese and its distribution in different compartments of these trees (leaves, twigs, branches, trunk wood, trunk bark and roots) were studied. The average manganese concentrations in the aboveground compartments of red maple, white birch and red spruce trees were within the range of manganese concentrations reported in the literature for these trees. The concentrations of manganese in the aboveground compartments of red maple, white birch and red spruce trees in the reference site were significantly greater than those in the constructed wetland (with the exception of manganese concentrations in the trunk wood of red maple trees) because of the acidic soil conditions of the reference site. The percent distribution of manganese in the aboveground compartments of trees did not vary during the growing season. Higher concentrations of manganese were present in the trunk bark and either the leaves or twigs of species on both the constructed wetland and the reference site regardless of the sampling date.
\end{abstract}

Key words: Red maple, white birch, red spruce, manganese, seasonal variability, constructed wetland

\section{INTRODUCTION}

Plants have been described as solar driven pumps that can extract and concentrate metals from their environment $^{[1]}$. Plants extract metals from their soil and water environments because many metals are essential nutrients including magnesium, calcium, potassium, iron, manganese, copper, zinc and molybdenum. Plants also extract metals from their environments that have not been recognized as essential nutrients including chromium, lead, cadmium, mercury and nickel ${ }^{[2,3]}$. Metals in the environment originate from natural sources such as emissions from volcanoes and forest fires and the weathering of metal enriched rocks ${ }^{[4]}$ and from anthropogenic sources such as industrial activities, agricultural practices, atmospheric deposition and waste disposal operations ${ }^{[5-7]}$.

The retention of metals in specific compartments and their distribution to the tissues of the plant is highly species specific and depends on metal resistance mechanisms available to the plant such as chelation of metals, compartmentalization and organic ligand exudation ${ }^{[8,9]}$. In trees, metals exceeding the metabolic needs typically are transported to the extremities such as the bark, twig tips and leaves ${ }^{[10]}$.

In wetlands, flooded soils rapidly experience a decline in soil oxygen and redox potential resulting in anaerobic soil conditions. Facultative and obligate anaerobic microorganisms use carbon compounds as substrates and oxidized soil components as electron acceptors in respiration. Oxygen is the first soil component to be reduced followed by nitrate, manganese dioxide and ferric iron hydroxide ${ }^{[11,12]}$. As a result, flooded soils can have toxic concentrations of plant available nutrients such as iron and manganese compared to well drained soils ${ }^{[13]}$.

The objectives of this study were: (a) to compare the uptake of manganese by native tree species growing under flooded soil conditions in a constructed wetland and those growing under well drained soil conditions in a nearby forest, (b) to evaluate the seasonal variability of manganese in these trees and (c) to determine the distribution of manganese in different compartments of these trees (leaves, twigs, branches, trunk wood, trunk bark and roots).

Corresponding Author: A. E. Ghaly, Professor, Department of Process Engineering and Applied Science, Dalhousie University, Halifax, Nova Scotia, Canada 


\section{MATERIALS AND METHODS}

Burnside constructed wetland: A surface flow constructed wetland was established in the Burnside Industrial Park, Dartmouth, Nova Scotia, to treat stormwater runoff from the surrounding watersheds which are comprised primarily of commercial properties and two former landfills (a 5.34 ha site that operated from 1968 to 1974 and a 5.42 ha site that operated from 1976 to 1977). The aim was to protect a freshwater ecosystem that consists of a $4.6 \mathrm{~km}$ long brook (Wright's Brook) and two lakes (Enchanted Lake and Flat Lake). The results (Table 1) of a previously conducted environmental site assessment ${ }^{\left[{ }^{14]}\right.}$ had determined that the water entering the brook contained average iron and manganese concentrations (15.508 and $3.029 \mathrm{mg} \mathrm{L}^{-1}$, respectively) that exceed the allowable limits established by the Canadian Water Quality Guidelines for the Protection of Aquatic Life ${ }^{[15,16]}$. The wetland consists of 9 deep open water cells that are separated by shallow internal vegetated berms and surrounded by a system of external berms with a surface area of $6300 \mathrm{~m}^{2}$ and 2 naturally vegetated islands that are surrounded by a system of external berms with a surface area of approximately 6100 $\mathrm{m}^{2}$. The wetland berms and cells were planted with a variety of native plant species such as Carex crinita (fringed sedge), Carex lurida (yellow green sedge), Juncus brevicaudatus (tweedy's rush), Juncus effusus (soft rush), Scripus validus (soft stem bulrush), Calamagrostis canadensis (bluejoint grass), Alisma plantagoaquatica (water plantain), Pontederia cordata (pickerelweed), Nymphaea alba (white waterlily) and Potamageton natans (pondweed). The two naturally vegetated islands consist of untamed early successional brush dominated by low shrubs such as Comptonia peregrina (sweet fern), Viburnum cassinoides (witherod) and Spiraea alba (meadowsweet), deciduous and evergreen trees such as Acer rubrum (red maple), Betula papyrifera (white birch) and Picea rubens (red spruce) and emergent macrophytes such as Typha latifolia (cattails).

Table 1: Heavy metal loads entering Wright's Brook ${ }^{[14]}$

\begin{tabular}{lcl}
\hline Element & $\begin{array}{c}\text { Average concentration } \\
\left(\mathrm{mg} \mathrm{L}^{-1}\right)\end{array}$ & $\begin{array}{c}\text { Guidelines } \\
\left(\mathrm{mg} \mathrm{L}^{-1}\right)\end{array}$ \\
\hline Aluminium & 7.720 & $0.005-0.100$ \\
Arsenic & 0.009 & 0.005 \\
Chromium & 0.013 & $0.001-0.009$ \\
Copper & 0.039 & $0.002-0.004$ \\
Iron & 15.508 & 0.300 \\
Lead & 0.075 & $0.001-0.007$ \\
Manganese & 3.029 & $1.000-1.500^{[16]}$ \\
Zinc & 0.158 & 0.030 \\
\hline
\end{tabular}

Selection of trees and sampling locations: A survey of the vegetated islands was conducted in order to identify dominant tree species. Based on the survey, two deciduous and one evergreen tree species were selected for this study. The two deciduous species included: Acer rubrum (red maple) and Betula papyrifera (white birch) and the evergreen species was Picea rubens (red spruce). Samples of leaves, twigs, branches, trunk bark, trunk wood and roots from trees were collected from the two naturally vegetated islands in the constructed wetland and from a reference site. The reference site was a forested area located to the south west of the islands. It was not influenced by stormwater runoff or leachate from the former landfills and it was never flooded during the study period. According to MacDougall et al. ${ }^{[17]}$, the soil in the reference site was porous and well drained. A total of six trees from each of red maple, white birch and red spruce were sampled (three trees from the naturally vegetated islands and three trees from the reference site). The sampling locations are shown in Fig. 1.

Sample collection: In season one, plant samples were collected when element concentrations were most stable. Element concentrations in evergreen species are most stable during the dormant season, which is typically from September through early March while element concentrations in deciduous species are most stable late in the growing season approximately two weeks before the onset of autumn coloration ${ }^{[18]}$. Therefore, plant samples were collected during the second and third weeks of September 2005. In season two, plant samples were collected in June 2006, July 2006 and August 2006. Samples of leaves were also collected in September and October 2006 upon senescence.

Samples of leaves, twigs and branches were collected with hand pruners, long handled pruners and a telescopic pruning pole. For both evergreen and deciduous species, samples of leaves or needles ( whole, well formed and current year growth) and were collected from several branches representing various sides of the middle part of the live crown of each tree. Approximately 20 leaves per deciduous tree were collected and mixed to make one sample. Enough needles and twigs were collected per evergreen tree to fill an $18 \times 15 \mathrm{~cm}$ plastic bag. To minimize serious injury to the trees, only one branch per tree was collected, cut into 6 inch lengths and mixed to make one sample. Wood and bark samples were collected from the trunk of each tree at breast height (1.3 $\mathrm{m})$. An axe was used to peel off a sample of bark and a $25.4 \mathrm{~cm}$ increment borer (SUUNTO, Vantaa, Finland) with three threads and an inner bit diameter of $5 \mathrm{~mm}$ was 
used to collect a wood core. Two parallel wood cores were obtained from each sampled trunk and mixed to make one sample. Samples of roots were collected from each tree in an area between the outer branch tips and trunk. A stainless steel spade was used to expose a portion of roots around each tree and samples were collected using long handled pruners. Samples were placed in labeled resealable plastic bags and stored in a cooler $\left(5^{\circ} \mathrm{C}\right)$. All samples were transported to the laboratory within $8 \mathrm{~h}$ and stored in a refrigerator at $4^{\circ} \mathrm{C}$. Preparation of plant samples involved decontamination, oven drying and particle size reduction.

Decontamination of samples: According to Mills and Jones $\mathrm{Jr}^{[2]}$, when plant materials are covered with soil, dust particles or spray materials, decontamination is required. Horwitz ${ }^{[19]}$ stated that the decontamination process should be performed quickly and excess washing of plant tissue, especially leaves, should be avoided to prevent leaching of minerals. However, tissue exposed to frequent rainfall such as leaves, twigs and branches need not be washed. Therefore, only root samples were washed with tap water to remove soil prior to drying.

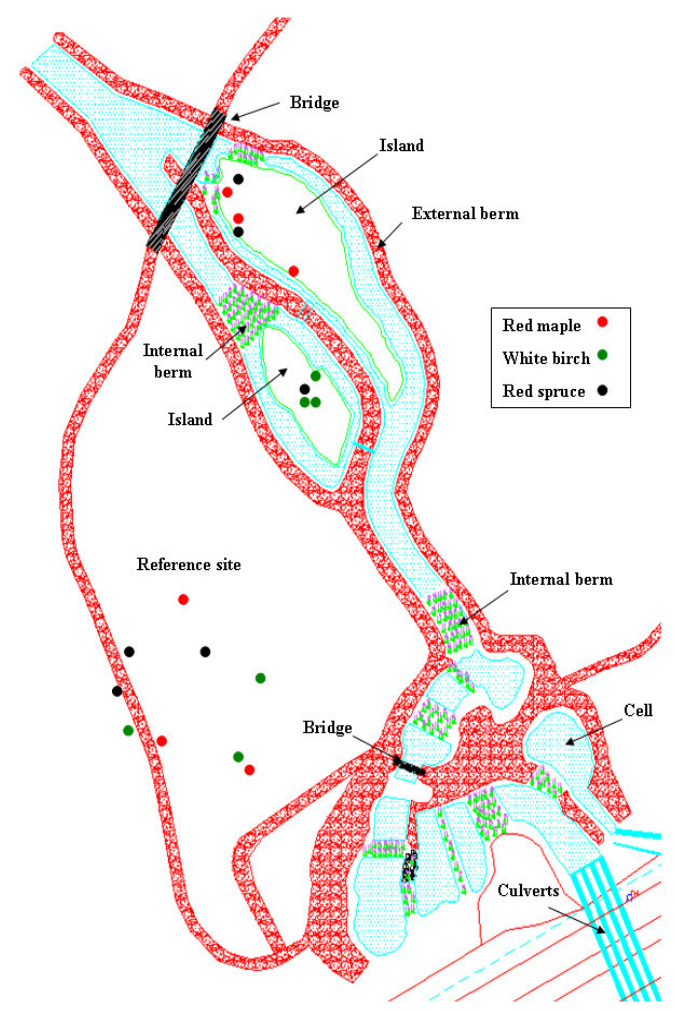

Fig. 1: Location of sampled trees
Drying of samples: Plant materials should be dried to minimize decomposition or weight loss by respiration at a temperature high enough to destroy the enzymes responsible for decomposition and sufficient for moisture removal, but below the temperature of thermal decomposition. Enzymes present in plant tissues are inactivated at temperatures above $60^{\circ} \mathrm{C}^{[20]}$. Therefore, plant tissues were placed in brown paper bags and oven dried at a temperature of $80^{\circ} \mathrm{C}$ for approximately $48 \mathrm{~h}$ in a laboratory oven (Isotemp Oven, Model \# 655F, Fisher Scientific Co., Ontario, Canada).

Particle size reduction: Samples of leaves were removed from the brown paper bags and placed into resealable plastic bags and reduced in size by manually crushing the dried samples. Samples of twigs, trunk bark and trunk wood were reduced in size by hand cutting using hand pruners and then by grinding in a coffee grinder (Toastmaster, Model \# 1119CAN, China). Samples of branches and roots were reduced in size by hand cutting using long handled pruners and then by grinding in a coffee grinder.

Sample analysis: Prepared samples were stored in air tight plastic containers in a refrigerator $\left(4^{\circ} \mathrm{C}\right)$ until they were delivered to the Minerals Engineering Center at Dalhousie University, Halifax, Nova Scotia and analyzed for total manganese concentrations. A wet acid digestion procedure was performed for destruction of organic matter present in plant samples. Initially, $1.0 \mathrm{~g}$ of dried, ground sample was placed in a Teflon beaker and $30 \mathrm{~mL}$ $(38 \% \mathrm{HCl})$ hydrochloric acid (Cat. \# A144-S212, Fisher Scientific Co., Ontario, Canada), $10 \mathrm{~mL}\left(70 \% \mathrm{HNO}_{3}\right)$ nitric acid (Cat. \# A200-212, Fisher Scientific Co., Ontario, Canada), $10 \mathrm{~mL}$ (49\% HF) hydrofluoric acid (Cat. \# A147-1LB, Fisher Scientific Co., Ontario, Canada) and $5 \mathrm{~mL}\left(70 \% \mathrm{HCLO}_{4}\right)$ perchloric acid (Cat. \# A2296-1LB, Fisher Scientific Co., Ontario, Canada) were added. Under a fume hood, the samples were heated to dryness (overnight) on a hot plate (Model \# SP46925, Barnstead/Thermolyne, Dubuque, Iowa) at a temperature of $125^{\circ} \mathrm{C}$. Then, $10 \mathrm{~mL}$ of $\mathrm{HCl}$ and $30 \mathrm{~mL}$ of $\mathrm{H}_{2} \mathrm{O}$ were added to dissolve the residue. Under a fume hood, the samples were heated on a hot plate at a temperature of $125^{\circ} \mathrm{C}$ for $30 \mathrm{~min}$. The samples were filtered through Fisher \# 4 filter paper (Cat. \# 09-803-6A, Fisher Scientific Co., Ontario, Canada) and the filtrate was collected in a $100 \mathrm{~mL}$ volumetric glass flask and made up to a final volume of $100 \mathrm{~mL}$ with distilled-deionized water. Manganese concentrations were determined by inductively coupled plasma optical emission spectroscopy (Vista Pro, Varian Inc., Victoria, Australia) with a detection limit of $0.25 \mathrm{ppm}$ for $\mathrm{Mn}$.

Statistical analysis: The data was analyzed statistically 
using a one-way analysis of variance. The statistical analyses were performed using SPSS (SPSS Inc., SPSS 14.0.1, Chicago, IL) and differences were considered significant at a $\mathrm{p}$-value $=0.05$ (95\% confidence interval) .

\section{RESULTS AND DISCUSSION}

Uptake of manganese: Manganese is an essential micronutrient in plant nutrition and has several functions. Manganese is involved in photosynthesis, it is a constituent of some respiratory enzymes and enzymes responsible for protein synthesis and it functions in the formation of chlorophyll ${ }^{[13,21]}$. Symptoms of manganese deficiency include interveinal chlorosis of young leaves and brown speckling and bronzing with abscission of developing leaves. Uptake of excess concentrations of manganese by plants can result in deformed leaves, chlorotic areas, dead spots and stunted growth ${ }^{[13]}$. The manganese concentrations in the different compartments of each tree are shown in Tables 2-4. Tables 5-7 display the analysis of variance for the total manganese concentrations in the compartments of red maple, white birch and red spruce trees, respectively as affected by location.

Leaves: The average manganese concentrations in the leaves of red maple, white birch and red spruce trees in the constructed wetland ranged from 116 to $405 \mathrm{mg} \mathrm{kg}^{-1}$, from 252 to $426 \mathrm{mg} \mathrm{kg}^{-1}$ and from 104 to $168 \mathrm{mg} \mathrm{kg}^{-1}$, respectively. The average concentrations of manganese in the leaves of red maple, white birch and red spruce trees in the reference site ranged from 223 to $480 \mathrm{mg} \mathrm{kg}^{-1}$, from 553 to $852 \mathrm{mg} \mathrm{kg}^{-1}$ and from 351 to $920 \mathrm{mg} \mathrm{kg}^{-1}$.

The manganese concentrations in the leaves of trees examined in this study are within the range reported in the literature. Piczak ${ }^{[22]}$ observed average manganese concentrations of 41.3-700 and 106-409 $\mathrm{mg} \mathrm{kg}^{-1}$ in the leaves of Norway maple and weeping birch trees. Mankovska ${ }^{[23]}$ and Elowson and Rytter ${ }^{[24]}$ observed average manganese concentrations of 1025 and $450 \mathrm{mg} \mathrm{kg}^{-1}$ in the needles of Norway spruce and grey alder trees. Young and Guinn ${ }^{[25]}$ observed average manganese concentrations of 765,315 and $1400 \mathrm{mg} \mathrm{kg}^{-1}$ in the leaves of red maple, white birch and red spruce trees, respectively.

The low, normal and high concentrations of manganese in dried plant leaves are 5, 20-400 and $2000 \mathrm{mg} \mathrm{kg}^{-1}$, respectively ${ }^{[26]}$. The average manganese concentrations in the leaves of the sampled trees fall within or above the normal range for manganese in dried plant leaves.

The statistical analysis showed that the concentrations of manganese in the leaves of red maple, white birch and red spruce trees in the reference site were significantly greater than those in the leaves of trees in the constructed wetland ( $\mathrm{p}$-values $=0.056,0.001$ and 0.000). High levels of manganese in the leaves and needles of trees have been associated with acidic soils ${ }^{[27-31]}$. Lin et al. ${ }^{[28]}$ observed manganese concentrations in the range of 552$896 \mathrm{mg} \mathrm{kg}^{-1}$ in the needles of balsam fir trees that were growing in soil with an average $\mathrm{pH}$ of 3.75 . Kolb and McCormick ${ }^{[29]}$ observed average manganese concentrations of 2459 and $2452 \mathrm{mg} \mathrm{kg}^{-1}$ in the leaves of sugar maple trees that were growing in soil with an average $\mathrm{pH}<4$.1. Kazda and $\mathrm{Zvacek}^{[30]}$ observed average manganese concentrations of $704 \pm 389 \mathrm{mg} \mathrm{kg}^{-1}$ in the needles of Norway spruce trees that were growing in soil with an average $\mathrm{pH}<4.0$.

Twigs: The average manganese concentrations in the twigs of red maple, white birch and red spruce trees in the constructed wetland ranged from 162 to $178 \mathrm{mg} \mathrm{kg} \mathrm{kg}^{-1}$, from 104 to $121 \mathrm{mg} \mathrm{kg}^{-1}$ and from 77 to $93 \mathrm{mg} \mathrm{kg}^{-1}$, respectively. The average manganese concentrations in the twigs of red maple, white birch and red spruce trees in the reference site ranged from 273 to $313 \mathrm{mg} \mathrm{kg}^{-1}$, from 159 to $225 \mathrm{mg} \mathrm{kg}^{-1}$ and from 436 to $590 \mathrm{mg} \mathrm{kg}^{-1}$, respectively.

The average manganese concentrations in the twigs of the sampled trees agree with reported values in the literature. McColl ${ }^{[32]}$ observed average manganese concentrations of $250 \mathrm{mg} \mathrm{kg}^{-1}$ in the twigs of blue gum eucalyptus trees. Brotherson and Osayande ${ }^{[33]}$ observed average manganese concentrations of 12.0 and $13.1 \mathrm{mg} \mathrm{kg}^{-1}$ in the twigs of mountain mahogany and Utah juniper trees. Young and Guinn ${ }^{[25]}$ observed average manganese concentrations of 475,129 and $580 \mathrm{mg} \mathrm{kg}^{-1}$ in the twigs of red maple, white birch and red spruce trees, respectively.

The statistical analysis showed that the concentrations of manganese in the twigs of red maple, white birch and red spruce trees in the reference site were significantly greater than those in the twigs of trees in the constructed wetland (p-values $=0.001,0.000$ and 0.000). A review of the literature revealed one study by Sailerova and Fedikow $^{[10]}$ who reported that the average manganese concentrations in the twigs of black spruce trees growing on well drained sites was significantly greater than those in trees growing on poorly drained sites.

Branches: The average manganese concentrations in the branches of red maple, white birch and red spruce trees in the constructed wetland ranged from 78 to $117 \mathrm{mg} \mathrm{kg}^{-1}$, from 69 to $85 \mathrm{mg} \mathrm{kg}^{-1}$ and from 59 to $115 \mathrm{mg} \mathrm{kg}^{-1}$, respectively. The average manganese concentrations in the branches of red maple, white birch and red spruce trees in 
OnLine J. Biol. Sci., 7 (1): 30-43, 2007

Table 2: Average Mn concentrations $\left(\mathrm{mg} \mathrm{kg}^{-1}\right)$ in red maple trees

\begin{tabular}{|c|c|c|c|c|c|c|c|c|c|c|}
\hline \multirow{3}{*}{ Compartment } & \multicolumn{5}{|c|}{ Wetland } & \multicolumn{5}{|c|}{ Reference Site } \\
\hline & \multirow{2}{*}{$\begin{array}{l}2005 \\
\text { Sept }\end{array}$} & \multicolumn{4}{|c|}{2006} & \multirow{2}{*}{$\begin{array}{l}2005 \\
\text { Sept }\end{array}$} & \multicolumn{4}{|c|}{2006} \\
\hline & & Jun & Jul & Aug & Sept & & Jun & Jul & Aug & Sept \\
\hline Leaves & $\begin{array}{l}329 \\
(228)\end{array}$ & $\begin{array}{l}116 \\
(86)\end{array}$ & $\begin{array}{l}167 \\
(88)\end{array}$ & $\begin{array}{l}274 \\
(175)\end{array}$ & $\begin{array}{l}405 \\
(321)\end{array}$ & $\begin{array}{l}420 \\
(197)\end{array}$ & $\begin{array}{l}223 \\
(88)\end{array}$ & $\begin{array}{l}334 \\
(158)\end{array}$ & $\begin{array}{l}480 \\
(236)\end{array}$ & $\begin{array}{l}557 \\
(198)\end{array}$ \\
\hline Twigs & $\begin{array}{l}162 \\
(38)\end{array}$ & $\begin{array}{l}176 \\
(54)\end{array}$ & $\begin{array}{l}172 \\
(54)\end{array}$ & $\begin{array}{l}178 \\
(115)\end{array}$ & $\begin{array}{l}- \\
-\end{array}$ & $\begin{array}{l}273 \\
(95)\end{array}$ & $\begin{array}{l}313 \\
(48)\end{array}$ & $\begin{array}{l}280 \\
(98)\end{array}$ & $\begin{array}{l}281 \\
(96)\end{array}$ & - \\
\hline Branches & $\begin{array}{l}91 \\
(24)\end{array}$ & $\begin{array}{l}86 \\
(12)\end{array}$ & $\begin{array}{l}78 \\
(22)\end{array}$ & $\begin{array}{l}117 \\
(46)\end{array}$ & - & $\begin{array}{l}138 \\
(12)\end{array}$ & $\begin{array}{l}143 \\
(50)\end{array}$ & $\begin{array}{l}101 \\
(22)\end{array}$ & $\begin{array}{l}152 \\
(36)\end{array}$ & - \\
\hline Trunk wood & $\begin{array}{l}32 \\
(5)\end{array}$ & $\begin{array}{l}47 \\
(23)\end{array}$ & $\begin{array}{l}25 \\
(6)\end{array}$ & $\begin{array}{l}37 \\
(6)\end{array}$ & - & $\begin{array}{l}46 \\
(6)\end{array}$ & $\begin{array}{l}43 \\
(17)\end{array}$ & $\begin{array}{l}52 \\
(18)\end{array}$ & $\begin{array}{l}39 \\
(12)\end{array}$ & - \\
\hline Trunk bark & $\begin{array}{l}244 \\
(38)\end{array}$ & $\begin{array}{l}223 \\
(39)\end{array}$ & $\begin{array}{l}233 \\
(61)\end{array}$ & $\begin{array}{l}214 \\
(70)\end{array}$ & - & $\begin{array}{l}388 \\
(89)\end{array}$ & $\begin{array}{l}386 \\
(79)\end{array}$ & $\begin{array}{l}358 \\
(76)\end{array}$ & $\begin{array}{l}393 \\
(123)\end{array}$ & - \\
\hline Roots & $\begin{array}{l}98 \\
(32)\end{array}$ & - & $\begin{array}{l}- \\
-\end{array}$ & $\begin{array}{l}128 \\
(57)\end{array}$ & - & $\begin{array}{l}133 \\
(77)\end{array}$ & - & - & $\begin{array}{l}105 \\
(57)\end{array}$ & - \\
\hline
\end{tabular}

- Samples were not collected, () Standard deviation

Table 3: Average Mn concentrations $\left(\mathrm{mg} \mathrm{kg}^{-1}\right)$ in white birch trees

\begin{tabular}{|c|c|c|c|c|c|c|c|c|c|c|}
\hline \multirow{3}{*}{ Compartment } & \multicolumn{5}{|c|}{ Wetland } & \multicolumn{5}{|c|}{ Reference } \\
\hline & \multirow{2}{*}{$\begin{array}{l}2005 \\
----- \\
\text { Sept }\end{array}$} & \multicolumn{4}{|c|}{2006} & \multirow{2}{*}{$\begin{array}{l}2005 \\
---1 \\
\text { Sept }\end{array}$} & \multicolumn{4}{|c|}{2006} \\
\hline & & Jun & Jul & Aug & Sept & & Jun & Jul & Aug & Sept \\
\hline Leaves & $\begin{array}{l}273 \\
(44)\end{array}$ & $\begin{array}{l}252 \\
(131)\end{array}$ & $\begin{array}{l}316 \\
(101)\end{array}$ & $\begin{array}{l}352 \\
(154)\end{array}$ & $\begin{array}{l}426 \\
(189)\end{array}$ & $\begin{array}{l}852 \\
(586)\end{array}$ & $\begin{array}{l}553 \\
(229)\end{array}$ & $\begin{array}{l}694 \\
(348)\end{array}$ & $\begin{array}{l}695 \\
(281)\end{array}$ & $\begin{array}{l}540 \\
(48)\end{array}$ \\
\hline Twigs & $\begin{array}{l}105 \\
(35)\end{array}$ & $\begin{array}{l}104 \\
(38)\end{array}$ & $\begin{array}{l}109 \\
(15)\end{array}$ & $\begin{array}{l}121 \\
(31)\end{array}$ & $\begin{array}{l}- \\
-\end{array}$ & $\begin{array}{l}177 \\
(82)\end{array}$ & $\begin{array}{l}159 \\
(7)\end{array}$ & $\begin{array}{l}225 \\
(67)\end{array}$ & $\begin{array}{l}218 \\
(54)\end{array}$ & - \\
\hline Branches & $\begin{array}{l}69 \\
(16)\end{array}$ & $\begin{array}{l}83 \\
(14)\end{array}$ & $\begin{array}{l}85 \\
(22)\end{array}$ & $\begin{array}{l}84 \\
(19)\end{array}$ & - & $\begin{array}{l}163 \\
(59)\end{array}$ & $\begin{array}{l}164 \\
(36)\end{array}$ & $\begin{array}{l}170 \\
(47)\end{array}$ & $\begin{array}{l}196 \\
(15)\end{array}$ & - \\
\hline Trunk wood & $\begin{array}{l}34 \\
(8)\end{array}$ & $\begin{array}{l}35 \\
(1)\end{array}$ & $\begin{array}{l}46 \\
(29)\end{array}$ & $\begin{array}{l}24 \\
(6)\end{array}$ & - & $\begin{array}{l}77 \\
(24)\end{array}$ & $\begin{array}{l}72 \\
(15)\end{array}$ & $\begin{array}{l}65 \\
(18)\end{array}$ & $\begin{array}{l}64 \\
(15)\end{array}$ & - \\
\hline Trunk bark & $\begin{array}{l}1033 \\
(411)\end{array}$ & $\begin{array}{l}1054 \\
(278)\end{array}$ & $\begin{array}{l}1087 \\
(122)\end{array}$ & $\begin{array}{l}985 \\
(113)\end{array}$ & - & $\begin{array}{l}1374 \\
(383)\end{array}$ & $\begin{array}{l}1178 \\
(147)\end{array}$ & $\begin{array}{l}1332 \\
(194)\end{array}$ & $\begin{array}{l}1158 \\
(262)\end{array}$ & - \\
\hline Roots & $\begin{array}{l}118 \\
(34)\end{array}$ & - & - & $\begin{array}{l}262 \\
(154)\end{array}$ & - & $\begin{array}{l}90 \\
(50)\end{array}$ & - & - & $\begin{array}{l}254 \\
(161)\end{array}$ & - \\
\hline
\end{tabular}

- Samples were not collected, () Standard deviation

Table 4: Average Mn concentrations $\left(\mathrm{mg} \mathrm{kg}^{-1}\right)$ in red spruce trees

\begin{tabular}{|c|c|c|c|c|c|c|c|c|}
\hline \multirow{3}{*}{ Compartment } & \multicolumn{4}{|c|}{ Wetland } & \multicolumn{4}{|c|}{ Reference } \\
\hline & \multirow{2}{*}{\begin{tabular}{l}
2005 \\
\hdashline$-{ }^{-}$ \\
Sept
\end{tabular}} & \multicolumn{3}{|c|}{2006} & \multirow{2}{*}{\begin{tabular}{l}
2005 \\
\hdashline Sept
\end{tabular}} & \multicolumn{3}{|c|}{2006} \\
\hline & & Jun & Jul & Aug & & Jun & Jul & Aug \\
\hline Leaves & $\begin{array}{l}168 \\
(54)\end{array}$ & $\begin{array}{l}104 \\
(51)\end{array}$ & $\begin{array}{l}143 \\
(56)\end{array}$ & $\begin{array}{l}165 \\
(64)\end{array}$ & $\begin{array}{l}887 \\
(392)\end{array}$ & $\begin{array}{l}351 \\
(302)\end{array}$ & $\begin{array}{l}464 \\
(112)\end{array}$ & $\begin{array}{l}920 \\
(299)\end{array}$ \\
\hline Twigs & $\begin{array}{l}77 \\
(12)\end{array}$ & $\begin{array}{l}81 \\
(13)\end{array}$ & $\begin{array}{l}88 \\
(13)\end{array}$ & $\begin{array}{l}93 \\
(14)\end{array}$ & $\begin{array}{l}590 \\
(328)\end{array}$ & $\begin{array}{l}436 \\
(196)\end{array}$ & $\begin{array}{l}485 \\
(203)\end{array}$ & $\begin{array}{l}565 \\
(208)\end{array}$ \\
\hline Branches & $\begin{array}{l}115 \\
(34)\end{array}$ & $\begin{array}{l}78 \\
(18)\end{array}$ & $\begin{array}{l}59 \\
(11)\end{array}$ & $\begin{array}{l}79 \\
(9)\end{array}$ & $\begin{array}{l}382 \\
(149)\end{array}$ & $\begin{array}{l}319 \\
(148)\end{array}$ & $\begin{array}{l}380 \\
(163)\end{array}$ & $\begin{array}{l}366 \\
(152)\end{array}$ \\
\hline Trunk Wood & $\begin{array}{l}52 \\
(6)\end{array}$ & $\begin{array}{l}38 \\
(3)\end{array}$ & $\begin{array}{l}39 \\
\text { (11) }\end{array}$ & $\begin{array}{l}37 \\
(3)\end{array}$ & $\begin{array}{l}186 \\
(24)\end{array}$ & $\begin{array}{l}151 \\
(54)\end{array}$ & $\begin{array}{l}149 \\
(59)\end{array}$ & $\begin{array}{l}137 \\
(49)\end{array}$ \\
\hline Trunk Bark & $\begin{array}{l}419 \\
(53)\end{array}$ & $\begin{array}{l}323 \\
(21)\end{array}$ & $\begin{array}{l}310 \\
(43)\end{array}$ & $\begin{array}{l}321 \\
(90)\end{array}$ & $\begin{array}{l}917 \\
(258)\end{array}$ & $\begin{array}{l}731 \\
(109)\end{array}$ & $\begin{array}{l}813 \\
(191)\end{array}$ & $\begin{array}{l}742 \\
(159)\end{array}$ \\
\hline Roots & $\begin{array}{l}98 \\
(27)\end{array}$ & - & - & $\begin{array}{l}80 \\
(35)\end{array}$ & $\begin{array}{l}156 \\
(140)\end{array}$ & - & - & $\begin{array}{l}349 \\
(82)\end{array}$ \\
\hline
\end{tabular}

- Samples were not collected, () Standard deviation 
OnLine J. Biol. Sci., 7 (1): 30-43, 2007

the reference site ranged from 101 to $152 \mathrm{mg} \mathrm{kg}^{-1}$, from 163 to $196 \mathrm{mg} \mathrm{kg}^{-1}$ and from 319 to $382 \mathrm{mg}$ $\mathrm{kg}^{-1}$,respectively. These values are comparable to data reported in the literature. Morrison and Hogan ${ }^{[34]}$, Schmitt et al. ${ }^{[35]}$ and Wittwer et al. ${ }^{[36]}$ observed average manganese

Table 5: One-way analysis of variance for the total Mn concentrations in the compartments of red maple trees as affected by location

\begin{tabular}{llllll}
\hline Source & DF & SS & MS & F & P \\
\hline Red maple leaves & & & & & \\
Total & 29 & 1258581 & & & \\
$\begin{array}{l}\text { Location } \\
\text { Error }\end{array}$ & 1 & 156819 & 156819 & 3.99 & 0.056 \\
Red maple twigs & 28 & 1101763 & 39349 & & \\
Total & 23 & 183686 & & & \\
$\begin{array}{l}\text { Location } \\
\text { Error }\end{array}$ & 1 & 78891 & 78891 & 16.56 & 0.001 \\
Red maple branches & 22 & 104795 & 4763 & & \\
$\begin{array}{l}\text { Total } \\
\text { Location }\end{array}$ & 23 & 32599 & & & \\
$\begin{array}{l}\text { Error } \\
\text { Red maple trunk wood }\end{array}$ & 1 & 9923 & 9923 & 9.63 & 0.005 \\
Total & 22 & 22676 & 1031 & & \\
$\begin{array}{l}\text { Location } \\
\text { Error }\end{array}$ & 23 & 4419 & & & \\
Red maple trunk bark & 1 & 523 & 523 & 2.95 & 0.100 \\
Total & 22 & 3897 & 177 & & \\
Location & 23 & 237000 & & & \\
$\begin{array}{l}\text { Error } \\
\text { Red maple roots }\end{array}$ & 1 & 139843 & 139843 & 31.67 & 0.000 \\
Total & 22 & 97157 & 4416 & & \\
Location & & & & & \\
Error & 11 & 29478 & & & \\
\hline Differces are cons & 1 & 108 & 108 & 0.04 & 0.852 \\
\hline & 10 & 29370 & 2937 & & \\
\hline
\end{tabular}

Differences are considered significant at a p-value $=0.05(95 \%$ confidence interval)

concentrations of $264-411,543$ and $304 \mathrm{mg} \mathrm{kg}^{-1}$ in the branches of sugar maple, white birch and red pine trees, respectively. Young and Guinn ${ }^{[25]}$ observed average manganese concentrations of 830, 273 and $1076 \mathrm{mg} \mathrm{kg}^{-1}$ in the branches of red maple, white birch and red spruce trees, respectively.

The statistical analysis showed that the concentrations of manganese in the branches of red maple, white birch and red spruce trees in the reference site were significantly greater than those in the branches of trees in the constructed wetland $(\mathrm{p}$-values $=0.005,0.000$ and 0.000). A review of the literature revealed no specific studies on the accumulation of manganese in the branches of trees growing on well drained acidic soils compared to saturated soils.

Trunk wood: The average manganese concentrations in the trunk wood of red maple, white birch and red spruce trees in the constructed wetland ranged from 25 to $47 \mathrm{mg} \mathrm{kg}^{-1}$, from 24 to $46 \mathrm{mg} \mathrm{kg}^{-1}$ and from 37 to $52 \mathrm{mg} \mathrm{kg}^{-1}$, respectively. The average manganese concentrations in the trunk wood of red maple, white birch and red spruce trees in the reference site ranged from 39 to $52 \mathrm{mg} \mathrm{kg}^{-1}$, from 64 to $77 \mathrm{mg} \mathrm{kg}^{-1}$ and from 137 to $186 \mathrm{mg} \mathrm{kg}^{-1}$, respectively.
Table 6: One-way analysis of variance for the total Mn concentrations in the compartments of white birch trees as affected by location

\begin{tabular}{|c|c|c|c|c|c|}
\hline Source & DF & SS & MS & $\mathrm{F}$ & $\mathrm{P}$ \\
\hline \multicolumn{6}{|c|}{ White birch leaves } \\
\hline Total & 29 & 2508391 & & & \\
\hline Location & 1 & 882711 & 882711 & 15.20 & 0.001 \\
\hline Error & 28 & 1625680 & 58060 & & \\
\hline \multicolumn{6}{|c|}{ White birch twigs } \\
\hline Total & 23 & 88742 & & & \\
\hline Location & 1 & 43350 & 43350 & 21.01 & 0.000 \\
\hline Error & 22 & 45392 & 2063 & & \\
\hline \multicolumn{6}{|c|}{ White birch branches } \\
\hline Total & 23 & 71761 & & & \\
\hline Location & 1 & 51894 & 51894 & 57.46 & 0.000 \\
\hline Error & 22 & 19867 & 903 & & \\
\hline \multicolumn{6}{|c|}{ White birch trunk wood } \\
\hline Total & 23 & 12974 & & & \\
\hline Location & 1 & 7350 & 7350 & 28.75 & 0.000 \\
\hline Error & 22 & 5624 & 256 & & \\
\hline \multicolumn{6}{|c|}{ White birch trunk bark } \\
\hline Total & 23 & 1511798 & & & \\
\hline Location & 1 & 292604 & 292604 & 5.28 & 0.031 \\
\hline Error & 22 & 1219194 & 55418 & & \\
\hline \multicolumn{6}{|c|}{ White birch roots } \\
\hline Total & 11 & 178319 & & & \\
\hline Location & 1 & 972 & 972 & 0.05 & 0.820 \\
\hline Error & 10 & 177347 & 17735 & & \\
\hline
\end{tabular}

Table 7: One-way analysis of variance for the total Mn concentrations in the compartments of red spruce trees as affected by location

\begin{tabular}{|c|c|c|c|c|c|}
\hline Source & $\mathrm{DF}$ & SS & MS & $\mathrm{F}$ & $\mathrm{P}$ \\
\hline \multicolumn{6}{|c|}{ Red spruce needles } \\
\hline Total & 23 & 3049082 & & & \\
\hline Location & 1 & 1562130 & \multicolumn{2}{|c|}{156213023.11} & 0.000 \\
\hline Error & 22 & 1486951 & \multicolumn{2}{|c|}{67589} & \\
\hline \multicolumn{6}{|c|}{ Red spruce twigs } \\
\hline Total & 23 & 1638807 & & & \\
\hline Location & 1 & 1129702 & \multicolumn{2}{|c|}{112970248.82} & 0.000 \\
\hline Error & 22 & 509105 & \multicolumn{2}{|c|}{23141} & \\
\hline \multicolumn{6}{|c|}{ Red spruce branches } \\
\hline Total & 23 & 3049082 & & & \\
\hline Location & 1 & 1562130 & \multicolumn{2}{|c|}{156213023.11} & 0.000 \\
\hline Error & 22 & 1486951 & 67589 & & \\
\hline \multicolumn{6}{|c|}{ Red spruce trunk wood } \\
\hline Total & 23 & 101705 & & & \\
\hline Location & 1 & 78204 & 78204 & 73.21 & 0.000 \\
\hline Error & 22 & 23500 & 1068 & & \\
\hline \multicolumn{6}{|c|}{ Red spruce trunk bark } \\
\hline Total & 23 & 1651574 & & & \\
\hline Location & 1 & 1255838 & \multicolumn{2}{|c|}{125583869.82} & 0.000 \\
\hline Error & 22 & 395736 & 17988 & & \\
\hline \multicolumn{6}{|c|}{ Red spruce roots } \\
\hline Total & 11 & 192625 & & & \\
\hline Location & 1 & 80033 & 80033 & 7.11 & 0.024 \\
\hline Error & 10 & 112591 & 11259 & & \\
\hline
\end{tabular}

Differences are considered significant at a p-value $=0.05(95 \%$ confidence interval

Saarela et $a l .^{[37]}$ observed average manganese concentrations of $32-83 \mathrm{mg} \mathrm{kg}^{-1}$ in the trunk wood of 
Scots pine trees. Basham and Cowling ${ }^{[38]}$ observed average manganese concentrations of 16 and $62 \mathrm{mg} \mathrm{kg}^{-1}$ in the trunk wood of weeping birch and European spruce trees. Young and Guinn ${ }^{[25]}$ observed average manganese concentrations of 72,34 and $144 \mathrm{mg} \mathrm{kg}^{-1}$ in the trunk wood of red maple, white birch and red spruce trees, respectively. Miller ${ }^{[39]}$ stated that elements such as manganese are typically present in dry wood at concentrations of $<100 \mathrm{mg} \mathrm{kg}^{-1}$. The average manganese concentrations in the trunk wood of the sampled tree species are all less than $100 \mathrm{mg} \mathrm{kg}^{-1}$ with the exception of the trunk wood from red spruce trees in the reference site.

The statistical analysis showed that the concentrations of manganese in the trunk wood of white birch and red spruce trees in the reference site were significantly greater than those in the trunk wood of trees in the constructed wetland ( $\mathrm{p}$-values $=0.000$ and 0.000 ). A review of the literature revealed no specific studies on the accumulation of manganese in the trunk wood of trees growing on well drained acidic soils compared to saturated soils.

Trunk bark: The average manganese concentrations in the trunk bark of red maple, white birch and red spruce trees in the constructed wetland ranged from 214 to $244 \mathrm{mg} \mathrm{kg}^{-1}$, from 985 to $1087 \mathrm{mg} \mathrm{kg}^{-1}$ and from 310 to $419 \mathrm{mg} \mathrm{kg}^{-1}$, respectively. The average manganese concentrations in the trunk bark of red maple, white birch and red spruce trees in the reference site ranged from 358 to $393 \mathrm{mg} \mathrm{kg}^{-1}$, from 1158 to $1374 \mathrm{mg} \mathrm{kg}^{-1}$ and 731 to $917 \mathrm{mg} \mathrm{kg}^{-1}$, respectively.

The average manganese concentrations in the trunk bark of the sampled species were within the range of values reported in other studies. Morrison and Hogan ${ }^{[34]}$ observed average manganese concentrations of $683 \mathrm{mg} \mathrm{kg}^{-1}$ in the trunk bark of sugar maple trees. Heinrichs and Mayer ${ }^{[40]}$ observed average manganese concentrations of 1600 and $355 \mathrm{mg} \mathrm{kg}^{-1}$ in the trunk wood of European beech and Norway spruce trees. Young and Guinn ${ }^{[25]}$ observed average manganese concentrations of 668,275 and $612 \mathrm{mg} \mathrm{kg}^{-1}$ in the trunk bark of red maple, white birch and red spruce trees, respectively.

The statistical analysis showed that the concentrations of manganese in the trunk bark of red maple, white birch and red spruce trees in the reference site were significantly greater than those in the trunk bark of trees in the constructed wetland $(\mathrm{p}$-values $=0.000,0.031$ and
0.000). A review of the literature revealed no specific studies on the accumulation of manganese in the trunk bark of trees growing on well drained acidic soils compared to saturated soils.

Roots: The average manganese concentrations in the roots of red maple, white birch and red spruce trees in the constructed wetland ranged from 98 to $128 \mathrm{mg} \mathrm{kg}^{-1}$, from 118 to $262 \mathrm{mg} \mathrm{kg}^{-1}$ and from 80 to $98 \mathrm{mg} \mathrm{kg}^{-1}$, respectively. The average manganese concentration in the roots of red maple, white birch and red spruce trees in the reference site ranged from 105 to $133 \mathrm{mg} \mathrm{kg}^{-1}$, from 90 to $254 \mathrm{mg} \mathrm{kg}^{-1}$ and from 156 to $349 \mathrm{mg} \mathrm{kg}^{-1}$, respectively.

Vogt et al. ${ }^{[41]}$ observed average manganese concentrations of 580 and $850 \mathrm{mg} \mathrm{kg}^{-1}$ in the roots of hemlock and fir trees. Rodriguez-Barrueco ${ }^{[42]}$ observed average manganese concentrations of $137-223 \mathrm{mg} \mathrm{kg}^{-1}$ in the roots of European alder trees. Turner et al. ${ }^{[43]}$ observed average manganese concentrations of $142 \mathrm{mg} \mathrm{kg}^{-1}$ in the roots of red alder trees. Young and Guinn ${ }^{[25]}$ observed average manganese concentrations of 657,122 and $892 \mathrm{mg} \mathrm{kg}^{-1}$ in the roots of red maple, white birch and red spruce trees, respectively.

The statistical analysis showed that only the concentrations of manganese in the roots of red spruce trees in the reference site were significantly greater than those in the roots of trees in the constructed wetland $(p$-value $=0.024)$. A review of the literature revealed no specific studies on the accumulation of manganese in the roots of trees growing on well drained acidic soils compared to saturated soils.

Seasonal variations in total manganese: The seasonal variations in the average total manganese concentrations in the various compartments of the different tree species are shown in Figs. 2-6. Seasonal changes in the uptake of manganese may be evident when plant samples are collected over an extended period of time and could be attributed to several factors including: (a) developmental changes during the growth of the plant, (b) weather conditions that affect the evapotranspiration rate of the plant, (c) shunting of metals to plant tissues such as leaves and (d) seasonal changes in the availability of metals in the soil ${ }^{[10,44]}$. Tables $8-12$ display the analysis of variance for the total manganese concentrations in the leaves, twigs, branches, trunk wood, trunk bark and roots of trees 
in the constructed wetland and the reference site as affected by the sampling date.

Leaves: The average manganese concentrations in the leaves of red maple trees in the constructed wetland and the reference site increased throughout the growing season from $116 \pm 86$ and $223 \pm 88 \mathrm{mg} \mathrm{kg}^{-1}$ in June 2006 to $405 \pm 321$ and $557 \pm 198 \mathrm{mg} \mathrm{kg}^{-1}$ in September 2006 . However, these increases were not significantly affected by the sampling date ( $\mathrm{p}$-values $=0.436$ and 0.271 ). The average manganese concentrations in the leaves of white birch trees in the constructed wetland and the reference site and red spruce trees in the constructed wetland were not significantly affected by the sampling date. The average manganese concentration in the needles of red spruce trees in the reference site was affected by the sampling date at a $90 \%$ confidence interval with a minimum value of $351 \pm 302 \mathrm{mg} \mathrm{kg}^{-1}$ in June 2006 .
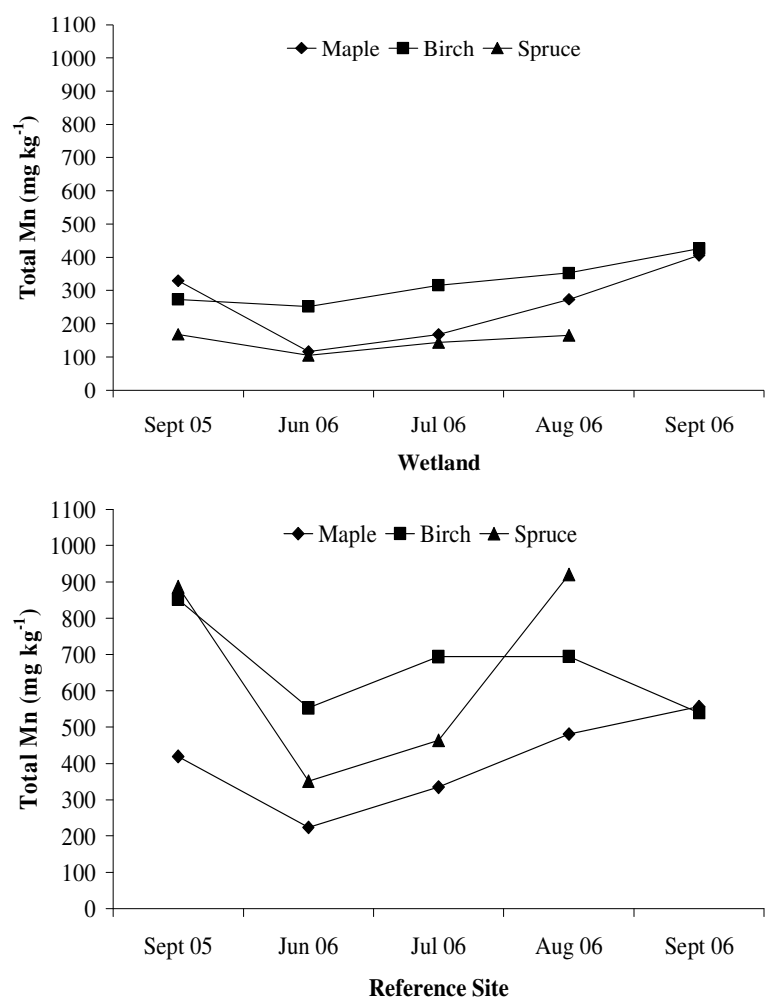

Fig. 2: Seasonal variability of $\mathrm{Mn}$ in the leaves of trees

Piczak et al. ${ }^{[22]}$ observed an increase in the concentration of manganese in the leaves of Norway maple trees during the growing season and reported that the average manganese concentration in the leaves of maple
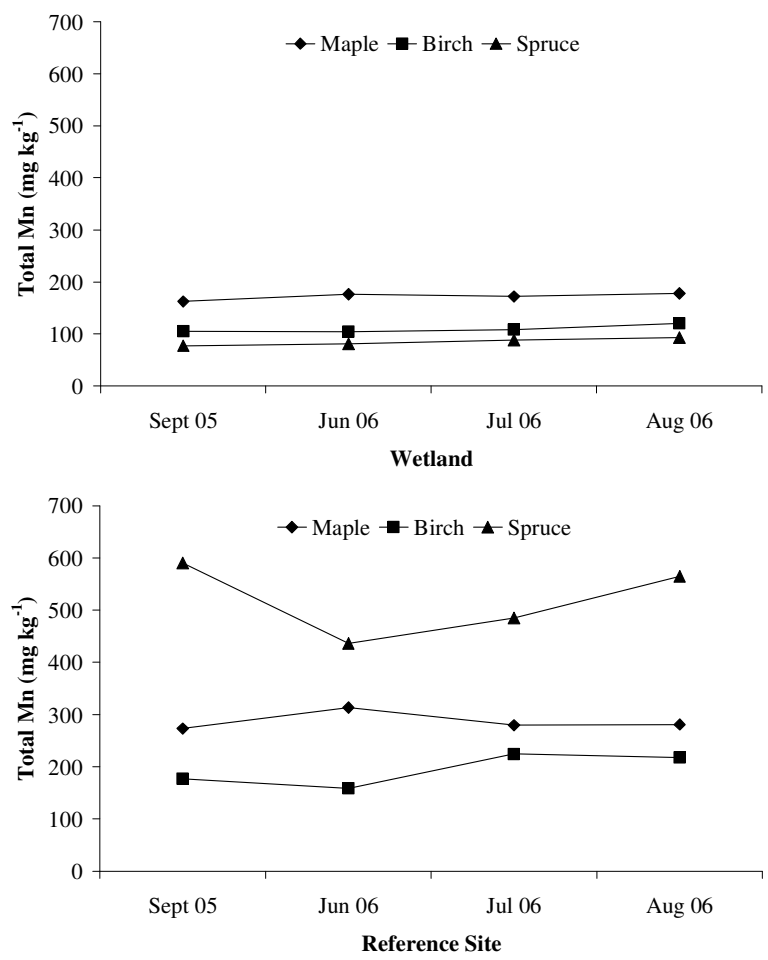

Fig. 3: Seasonal variability of Mn in the twigs of trees
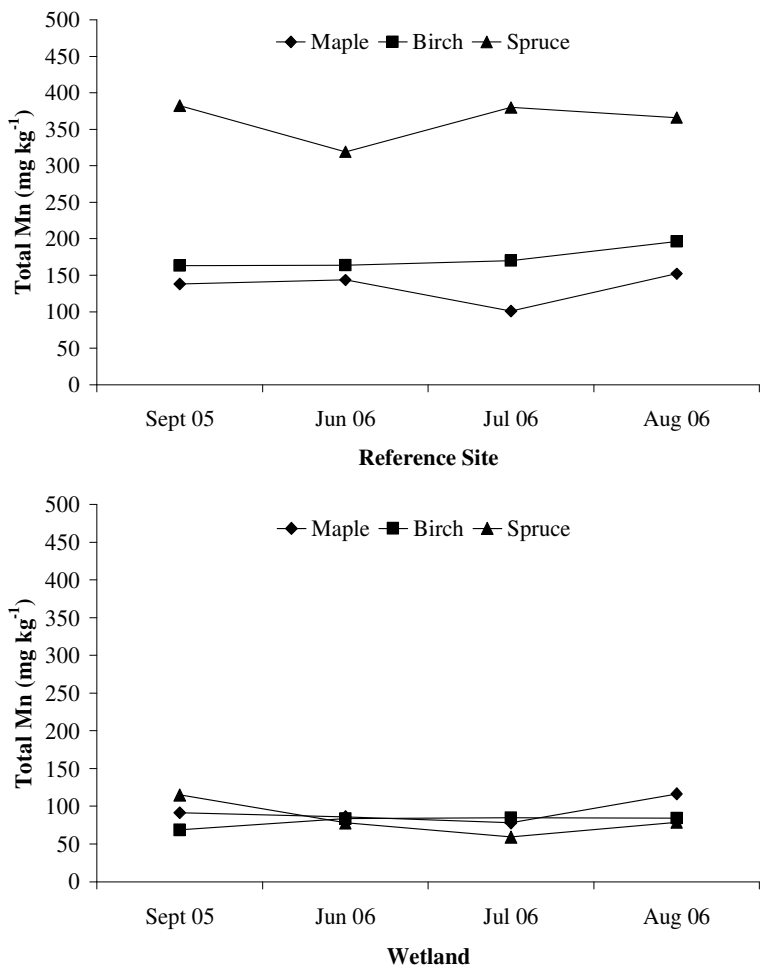

Fig. 4: Seasonal variability of $\mathrm{Mn}$ in the branches of trees 


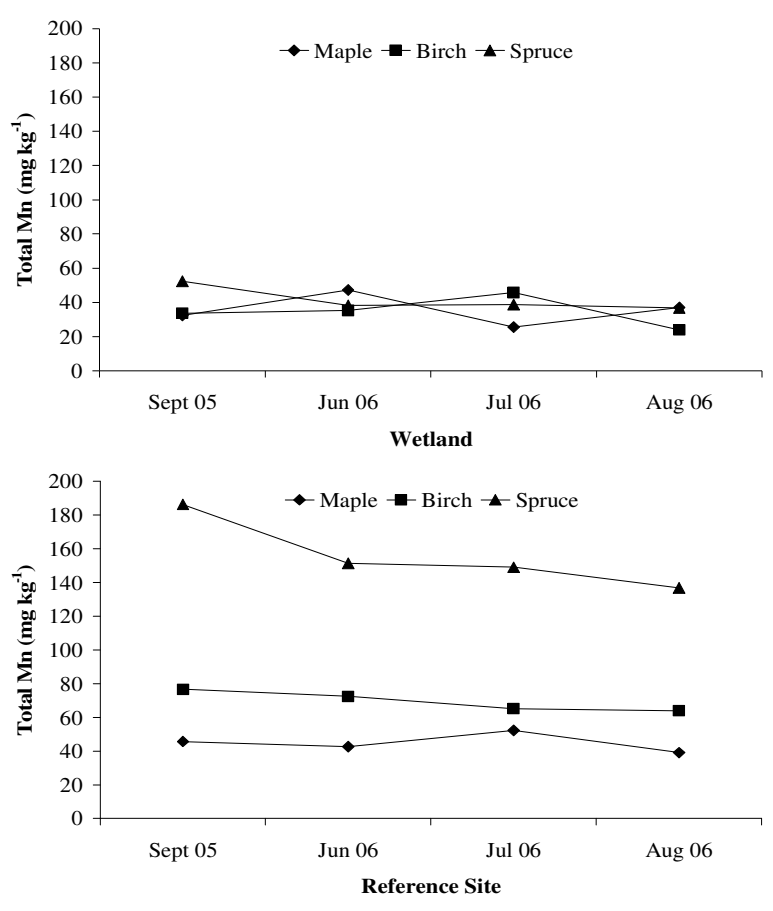

Fig. 5: Seasonal variability of Mn in the trunk wood of trees
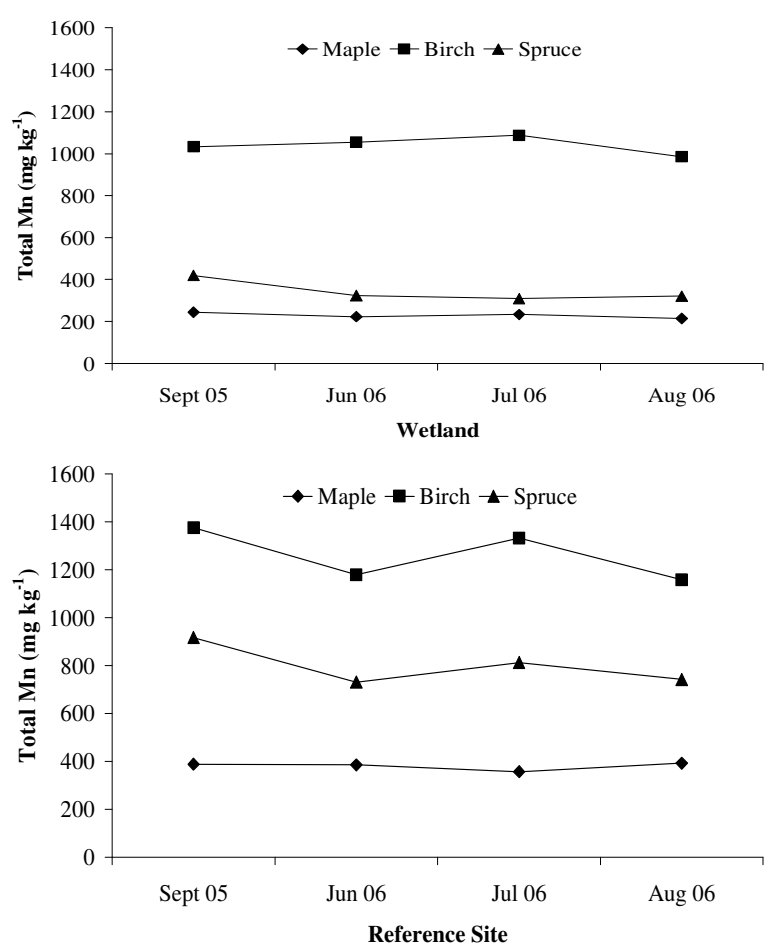

Fig. 6: Seasonal variability of $\mathrm{Mn}$ in the trunk bark of trees trees from three sampling sites increased from 41.3 to $70.4 \mathrm{mg} \mathrm{kg}^{-1}$, from 364 to $700 \mathrm{mg} \mathrm{kg}^{-1}$ and from 118 to $187 \mathrm{mg} \mathrm{kg}^{-1}$. Oleksyn et al. ${ }^{[45]}$ observed an accumulation of manganese in the leaves of silver birch trees during the growing season. They reported an increased average manganese concentration in the leaves from 237 $\mathrm{mg} \mathrm{kg}{ }^{-1}$ during leaf formation to $421 \mathrm{mg} \mathrm{kg}^{-1}$ during leaf senescence. Moorhead and McArthur ${ }^{[46]}$ observed an accumulation of manganese in the leaves of red maple trees during the growing season. Rodriguez-Barrueco et $a l .{ }^{[42]}$ observed an accumulation of manganese in the leaves of European alder trees prior to leaf fall and reported an increased average manganese concentration in the leaves from 269 to $1014 \mathrm{mg} \mathrm{kg}^{-1}$. Lea et al. ${ }^{[47]}$ observed a steady increase in the concentration of manganese in the leaves of sugar maple trees during the growing season and reported an increased average manganese concentration in the leaves from $820 \mathrm{mg} \mathrm{kg}^{-1}$ in June to $2130 \mathrm{mg} \mathrm{kg}^{-1}$ in October.

Twigs: The average manganese concentrations in the twigs of red maple, white birch and red spruce trees in the constructed wetland and the reference site were not significantly affected by the sampling date. A review of the literature revealed no specific studies on the seasonal variability of manganese in the twigs of trees.

Branches: The average manganese concentrations in the branches of red maple and white birch trees in the constructed wetland and the reference site and red spruce trees in the reference site were not significantly affected by the sampling date. The average manganese concentration in the branches of red spruce trees in the constructed wetland was significantly affected by the sampling date at a $90 \%$ confidence interval $(\mathrm{p}$-value $=$ 0.055 ) with a maximum concentration of $115 \pm 34 \mathrm{mg} \mathrm{kg}^{-1}$ in September 2005. A review of the literature revealed no specific studies on the seasonal variability of manganese in the branches of trees.

Trunk wood: The average manganese concentrations in the trunk wood of red maple and white birch trees in the constructed wetland and the reference site and red spruce trees in the reference site were not significantly affected by the sampling date. The average manganese concentrations in the trunk wood of red spruce trees in the constructed wetland were significantly affected by the sampling date at a $90 \%$ confidence interval $(\mathrm{p}$-value $=$ $0.064)$ with a maximum concentration of $52 \pm 6$ in September 2005. 
OnLine J. Biol. Sci., 7 (1): 30-43, 2007

Table 8: One-way analysis of variance for the total Mn concentrations in the leaves of trees in the constructed wetland and the reference site as affected by date

\begin{tabular}{|c|c|c|c|c|c|c|c|c|c|}
\hline \multirow[b]{2}{*}{ Source } & \multirow[b]{2}{*}{$\mathrm{DF}$} & \multicolumn{3}{|c|}{ Wetland } & \multirow[b]{2}{*}{$\mathrm{P}$} & \multicolumn{4}{|c|}{ Reference } \\
\hline & & SS & MS & $\mathrm{F}$ & & SS & MS & $\mathrm{F}$ & $\mathrm{P}$ \\
\hline \multicolumn{10}{|c|}{ Red maple leaves } \\
\hline Total & 14 & 568062.9 & & & & 533699.7 & & & \\
\hline Date & 4 & 166244.3 & 41561.1 & 1.034 & 0.436 & 201045.7 & 50261.4 & 1.511 & 0.271 \\
\hline Error & 10 & 401818.7 & 40181.9 & & & 332654.0 & 33265.4 & & \\
\hline \multicolumn{10}{|c|}{ White birch leaves } \\
\hline Total & 14 & 235457.3 & & & & 1390223 & & & \\
\hline Date & 4 & 57428.7 & 14357.2 & 0.806 & 0.548 & 194848.9 & 48712.2 & 0.408 & 0.799 \\
\hline Error & 10 & 178028.7 & 17802.9 & & & 1195374.0 & 119537.4 & & \\
\hline \multicolumn{10}{|c|}{ Red spruce leaves } \\
\hline Total & 11 & 33186.3 & & & & 1453765.0 & & & \\
\hline Date & 3 & 7724.9 & 2574.9 & 0.809 & 0.524 & 759747.7 & 253249.2 & 2.919 & 0.100 \\
\hline Error & 8 & 25461.3 & 3182.7 & & & 694017.3 & 86752.2 & & \\
\hline
\end{tabular}

Differences are considered significant at a p-value $=0.05$ (95\% confidence interval)

Table 9: One-way analysis of variance for the total Mn concentrations in the twigs of trees in the constructed wetland and the reference site as affected by

\begin{tabular}{|c|c|c|c|c|c|c|c|c|c|}
\hline \multirow[b]{2}{*}{ Source } & \multirow[b]{2}{*}{ DF } & \multicolumn{3}{|c|}{ Wetland } & \multirow[b]{2}{*}{$\mathrm{P}$} & \multicolumn{4}{|c|}{ Reference } \\
\hline & & SS & MS & $\mathrm{F}$ & & SS & MS & $\mathrm{F}$ & $\mathrm{P}$ \\
\hline \multicolumn{10}{|c|}{ Red maple twigs } \\
\hline Total & 11 & 41626.9 & & & & 63168.3 & & & \\
\hline Date & 3 & 424.9 & 141.6 & 0.028 & 0.993 & 2860.3 & 953.4 & 0.126 & 0.942 \\
\hline Error & 8 & 41202.0 & 5150.3 & & & 60308.0 & 7538.5 & & \\
\hline \multicolumn{10}{|c|}{ White birch twigs } \\
\hline Total & 11 & 8114.9 & & & & 37276.9 & & & \\
\hline Date & 3 & 488.3 & 162.8 & 0.171 & 0.913 & 9039.6 & 3013.2 & 0.854 & 0.503 \\
\hline Error & 8 & 7626.7 & 953.3 & & & 28237.3 & 3529.7 & & \\
\hline \multicolumn{10}{|c|}{ Red spruce twigs } \\
\hline Total & 11 & 1786.0 & & & & 507318.9 & & & \\
\hline Date & 3 & 466.0 & 155.3 & 0.941 & 0.465 & 45724.9 & 15241.6 & 0.264 & 0.849 \\
\hline Error & 8 & 1320.0 & 165.0 & & & 461594.0 & 57699.3 & & \\
\hline
\end{tabular}

Differences are considered significant at a p-value $=0.05$ (95\% confidence interval)

Table 10: One-way analysis of variance for the total Mn concentrations in the branches of trees in the constructed wetland and the reference site as affected by date

\begin{tabular}{|c|c|c|c|c|c|c|c|c|c|}
\hline \multirow[b]{2}{*}{ Source } & \multirow[b]{2}{*}{ DF } & \multicolumn{3}{|c|}{ Wetland } & \multirow[b]{2}{*}{$\mathrm{P}$} & \multicolumn{4}{|c|}{ Reference } \\
\hline & & SS & MS & $\mathrm{F}$ & & SS & MS & $\mathrm{F}$ & $\mathrm{P}$ \\
\hline \multicolumn{10}{|c|}{ Red maple branches } \\
\hline Total & 11 & 9250.9 & & & & 13424.9 & & & \\
\hline Date & 3 & 2540.9 & 846.9 & 1.010 & 0.437 & 4557.6 & 1519.2 & 1.371 & 0.320 \\
\hline Error & 8 & 6710.0 & 838.7 & & & 8867.3 & 1108.4 & & \\
\hline \multicolumn{10}{|c|}{ White birch branches } \\
\hline Total & 11 & 3116.7 & & & & 16750.7 & & & \\
\hline Date & 3 & 547.3 & 182.4 & 0.568 & 0.651 & 2202.0 & 734.0 & 0.404 & 0.755 \\
\hline Error & 8 & 2569.3 & 321.2 & & & 14548.7 & 1818.6 & & \\
\hline \multicolumn{10}{|c|}{ Red spruce branches } \\
\hline Total & 11 & 8228.3 & & & & 195784.3 & & & \\
\hline Date & 3 & 4882.9 & 1627.6 & 3.892 & 0.055 & 7798.9 & 2599.6 & 0.111 & 0.951 \\
\hline Error & 8 & 3345.3 & 418.2 & & & 187985.3 & 23498.2 & & \\
\hline
\end{tabular}

Differences are considered significant at a $\mathrm{p}$-value $=0.05$ (95\% confidence interval) 
OnLine J. Biol. Sci., 7 (1): 30-43, 2007

Table 11: One-way analysis of variance for the total Mn concentrations in the trunk wood of trees in the constructed wetland and the reference site as affected by date

\begin{tabular}{|c|c|c|c|c|c|c|c|c|c|}
\hline \multirow[b]{2}{*}{ Source } & \multirow[b]{2}{*}{ DF } & \multicolumn{3}{|c|}{ Wetland } & \multirow[b]{2}{*}{$\mathrm{P}$} & \multicolumn{4}{|c|}{ Reference } \\
\hline & & SS & MS & $\mathrm{F}$ & & SS & MS & $\mathrm{F}$ & $\mathrm{P}$ \\
\hline \multicolumn{10}{|c|}{ Red maple trunk wood } \\
\hline Total & 11 & 2055.0 & & & & 1841.7 & & & \\
\hline Date & 3 & 767.0 & 255.7 & 1.588 & 0.267 & 272.3 & 90.8 & 0.463 & 0.716 \\
\hline Error & 8 & 1288.0 & 161.0 & & & 1569.3 & 196.2 & & \\
\hline \multicolumn{10}{|c|}{ White birch trunk wood } \\
\hline Total & 11 & 2662.9 & & & & 2960.9 & & & \\
\hline Date & 3 & 730.3 & 243.4 & 1.008 & 0.438 & 338.3 & 112.8 & 0.344 & 0.795 \\
\hline Error & 8 & 1932.7 & 241.6 & & & 2622.7 & 327.8 & & \\
\hline \multicolumn{10}{|c|}{ Red spruce trunk wood } \\
\hline Total & 11 & 800.7 & & & & 22699.7 & & & \\
\hline Date & 3 & 461.3 & 153.8 & 3.625 & 0.064 & 4093.7 & 1364.6 & 0.587 & 0.641 \\
\hline Error & 8 & 339.3 & 42.4 & & & 18606.0 & 2325.8 & & \\
\hline
\end{tabular}

Differences are considered significant at a p-value $=0.05$ (95\% confidence interval)

Table 12: One-way analysis of variance for the total Mn concentrations in the trunk bark of trees in the constructed wetland and the reference site as affected by date

\begin{tabular}{|c|c|c|c|c|c|c|c|c|c|}
\hline \multirow[b]{2}{*}{ Source } & \multirow[b]{2}{*}{ DF } & \multicolumn{3}{|c|}{ Wetland } & \multirow[b]{2}{*}{$\mathrm{P}$} & \multicolumn{4}{|c|}{ Reference } \\
\hline & & SS & MS & $\mathrm{F}$ & & SS & MS & $\mathrm{F}$ & $\mathrm{P}$ \\
\hline \multicolumn{10}{|c|}{ Red maple trunk bark } \\
\hline Total & 11 & 24814.9 & & \multirow{3}{*}{0.171} & \multirow{3}{*}{0.913} & 72342.3 & & \multirow{3}{*}{0.087} & \multirow{3}{*}{0.965} \\
\hline Date & 3 & 1492.3 & 497.4 & & & 2296.9 & 765.6 & & \\
\hline Error & 8 & 23322.7 & 2915.3 & & & 70045.3 & 8755.7 & & \\
\hline \multicolumn{10}{|c|}{ White birch trunk bark } \\
\hline Total & 11 & 564128.7 & & \multirow{3}{*}{0.080} & \multirow{3}{*}{0.969} & 655065.0 & & \multirow{3}{*}{0.517} & \multirow{3}{*}{0.682} \\
\hline Date & 3 & 16384.7 & 5461.6 & & & 106395.0 & 35465.0 & & \\
\hline Error & 8 & 547744.0 & 68468.0 & & & 548670.0 & 68583.8 & & \\
\hline \multicolumn{10}{|c|}{ Red spruce trunk bark } \\
\hline Total & 11 & 49610.3 & & \multirow{3}{*}{2.393} & \multirow{3}{*}{0.144} & 346126.3 & & \multirow{3}{*}{0.626} & \multirow{3}{*}{0.618} \\
\hline Date & 3 & 23464.9 & 7821.6 & & & 65800.9 & 21933.6 & & \\
\hline Error & 8 & 26145.3 & 3268.2 & & & 280325.3 & 35040.7 & & \\
\hline
\end{tabular}

Differences are considered significant at a p-value $=0.05$ (95\% confidence interval)

A review of the literature revealed one study on the seasonal variability of manganese in the trunk wood of trees. Laureysens et al. ${ }^{[48]}$ observed that the average manganese concentration in the wood of poplar clones did not significantly increase or decrease during the growing season.

Trunk bark: The average manganese concentrations in the trunk bark of red maple, white birch and red spruce trees were not significantly affected by the sampling date. Laureysens et $a l .{ }^{[48]}$ also observed that the average manganese concentration in the bark of poplar clones did not significantly increase or decrease during the growing season.

Roots: The average manganese concentrations in the roots of red maple, white birch and red spruce trees were not significantly affected by the sampling date. However, a review of the literature revealed no specific studies on the seasonal variability of manganese in the roots of trees.
Manganese distribution within trees: Figure 7 displays the percent distribution of manganese in the above and belowground compartments of wetland and reference tree species. Higher concentrations of manganese were present in the trunk bark and either the leaves or twigs of species on both the constructed wetland and the reference site regardless of the sampling date.

Wittwer et al. ${ }^{[36]}$ and Zottl ${ }^{[49]}$ observed higher concentrations of manganese in the leaves and trunk bark of Norway spruce trees in Germany and of red pine trees in New York, respectively. Zottt ${ }^{[49]}$ noted that high concentrations of manganese in the trunk bark are typical for conifer trees growing on acid soils. Higher concentrations of manganese in the leaves and trunk bark of mature white birch trees were also observed by Schmitt et al. ${ }^{[35]}$ and Young and Guinn ${ }^{[25]}$.

Manganese was present in higher concentrations in the trunk bark of species compared to the trunk wood. In the constructed wetland, the average concentrations of manganese in the trunk bark of trees were 6.4-30.0 fold 

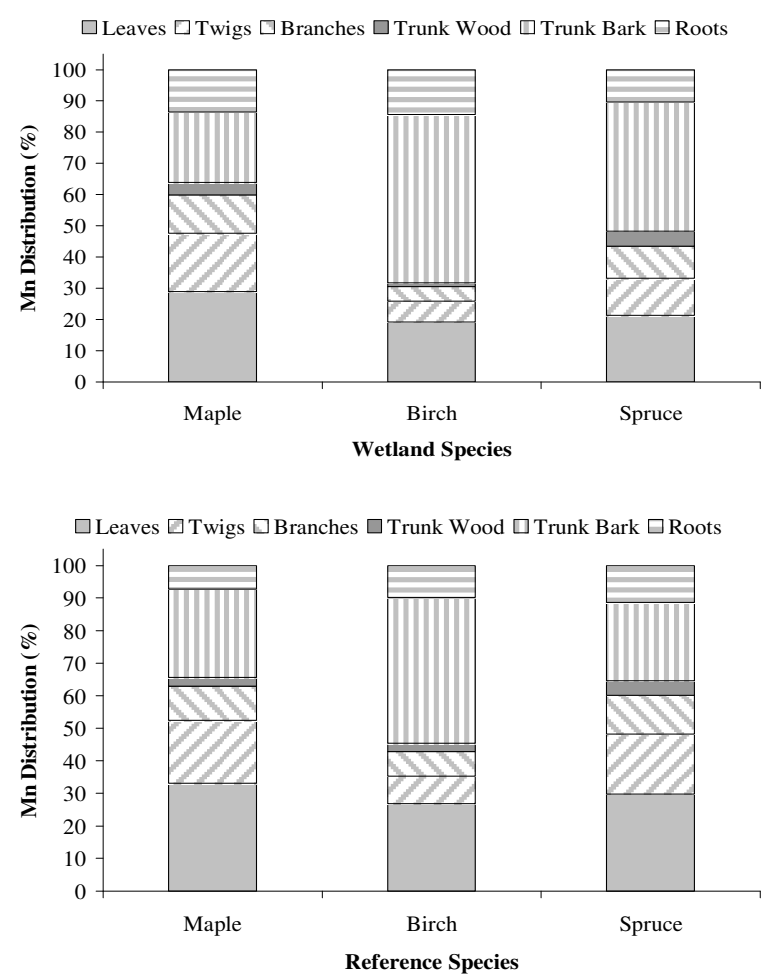

Fig. 7: Mn distribution (\%)

higher than the trunk wood concentrations. In the reference site, the average concentrations of manganese in the trunk bark were 5.1-18.1 fold higher than the trunk wood concentrations. Vogt et al. ${ }^{[41]}$ observed a 3.8 fold and a 2.6 fold increase in the concentrations of manganese in the trunk bark of fir and hemlock trees, respectively compared to the trunk wood concentrations. Morrison and Hogan $^{[34]}$, Schmitt et al. ${ }^{[35]}$, Wittwer et al. ${ }^{[36]}$ and Zottl ${ }^{[49]}$ observed a 9.9 fold, 5.6 fold, 2.6 fold and a 6.6 fold increase in the concentrations of manganese in the trunk bark compared to the trunk wood concentrations of sugar maple, Norway spruce, white birch and red pine trees, respectively. Young and Guinn ${ }^{[25]}$ observed a 4.3 fold, 8.1 fold and a 9.3 fold increase in the concentrations of manganese in the trunk bark of red spruce, white birch and red maple trees, respectively compared to the trunk wood concentrations. According to Heinrichs and Mayer ${ }^{[40]}$, high concentrations of manganese in the surface compartments of biomass, such as the leaves and bark, compared to the wood are caused by either selective uptake and storage of manganese in these compartments or deposition and fixation of atmospheric substances.

\section{CONCLUSIONS}

The average manganese concentrations in the aboveground compartments of red maple, white birch and red spruce trees were within the range of manganese concentrations reported in the literature for these trees. The concentrations of manganese in the aboveground compartments of red maple, white birch and red spruce trees in the reference site were significantly greater than those in the constructed wetland (with the exception of manganese concentrations in the trunk wood of red maple trees) because of the acidic soil conditions of the reference site. The percent distribution of manganese in the aboveground compartments of trees did not vary during the growing season. Higher concentrations of manganese were present in the trunk bark and either the leaves or twigs of species on both the constructed wetland and the reference site regardless of the sampling date. Manganese was present in higher concentrations in the trunk bark of species compared to the trunk wood. In the constructed wetland, the average concentrations of manganese in the trunk bark of trees were 6.4-30.0 fold higher than the trunk wood concentrations while in the reference site, the average concentrations of manganese in the trunk bark were 5.1-18.1 fold higher than the trunk wood concentrations.

\section{ACKNOWLEDGMENTS}

This research was funded by the ELJB Foundation of Montreal and Environment Canada.

\section{REFERENCES}

1. Salt, D.E., M. Blaylock, N.P.B.A. Kumar, V. Dushenkov, B.D. Ensley, I. Chet and I. Raskin, 1995. Phytoremediation: A novel strategy for the removal of toxic metals from the environment using plants. Biotechnology, 13 (5): 468-474.

2. Mills, H.A. and J.B. Jones, Jr., 1996. Plant Analysis Handbook II: A Practical Sampling, Preparation, Analysis and Interpretation Guide. MicroMacro Publishing Inc., Athens, Georgia.

3. Marschner, H., 1995. Mineral Nutrition of Higher Plants. Harcourt Brace and Company, New York, New York.

4. Ernst, W.H.O., 1998. The origin and ecology of contaminated, stabilized and non-pristine soils. In: Vangronsveld, J. and S.D. Cunningham (Eds.). Metal-Contaminated Soils: In situ Inactivation and Phytorestoration. Springer-Verlag, New York, New York, pp: 17-29. 
5. Alloway, B.J. and D.C. Ayres, 1993. Chemical Principles of Environmental Pollution. Blackie Academic and Professional, New York, New York.

6. Smith, Lawrence A., Jeffrey L. Means, Abraham Chen, Bruce Alleman, Christopher C. Chapman, John S. Tixier Jr., Susan E. Brauning, Arun R. Gavaskar and Micheal D. Royer, 1995. Remedial Options for Metals-Contaminated Sites. CRC Press, Boca Raton, Florida.

7. Vangronsveld, J. and S.D. Cunningham, 1998. Introduction to the concepts. In: Vangronsveld, J. and S.D. Cunningham (Eds.). Metal-Contaminated Soils: In situ Inactivation and Phytorestoration. SpringerVerlag, New York, New York, pp: 1-12.

8. Rougier, M. and A. Chaboud, 1985. Mucilage secreted by roots and their biological function. Israel J. Bot., 34 (2-4): 129-146.

9. Clemens, S., 2001. Molecular mechanisms of plant metal tolerance and homeostasis. Planta, 212 (4): 475-486.

10. Sailerova, E. and M.A.F. Fedikow, 2004. The effects of seasonal changes, sample site drainage and tree morphology on trace element contents of black spruce (Picea mariana) crown twigs and outer bark. Geochemistry: Exploration Environ. Anal., 4 (4): 365-379.

11. Faulkner, S.P. and C.J. Richardson, 1989. Physical and chemical characteristics of freshwater wetland soils. In: Hammer, D.A. (Ed.). Constructed Wetlands for Wastewater Treatment Municipal, Industrial and Agricultural. Lewis Publishers, New York, New York, pp: 41-72.

12. Ponnamperuma, F.N., 1972. The chemistry of submerged soils. In: Brady, N.C. (Ed.). Advances in Agronomy. Academic Press, New York, New York, pp: 29-96.

13. Adriano, D.C., 2001. Trace Elements in Terrestrial Environments. 2nd Edn., Springer-Verlag, New York, New York.

14. Ghaly, A.E. and R. Cote, 2001. Engineered Wetland Technology for Treatment of Industrial Park Contaminants, Technical Report, Dalhousie University, Halifax, Nova Scotia.

15. CCME., 2005. Canadian Environmental Quality Guidelines. Canadian Council of Ministers of the Environment, Winnipeg, Manitoba. Retrieved on August 20, 2006, from http://www.ccme.ca.

16. BCMELP., 2001. Ambient Water Quality Guidelines for Manganese. British Columbia Ministry of Environment, Lands and Parks, Vancouver, British Columbia. Retrieved September 14, 2002, from http://wlapwww.gov.bc.ca/wat/wq/BCguidelines/man ganese.html.
17. MacDougall, J.I., D.B. Cann and J.D. Hilchey, 1963. Soil survey of Halifax County, Nova Scotia. Retrieved on February 27, 2007, from http://www.sis.agr.gc.ca.

18. Canadian Forest Service, 1994. Canada's National Forest Health Monitoring Plot Network: Foliage Sampling and Analysis. Retrieved on May 30, 2005, from http://www.eman-rese.ca.

19. Horwitz, W., 2000. Official methods of analysis of AOAC International. 17th Edn., AOAC International, Arlington, Virginia.

20. Westerman, R.L., 1990. Soil testing and plant analysis. 3rd Edn., Soil Science Society of America, Madison, Wisconsin.

21. Decoteau, D.R., 2005. Principles of Plant Science. Pearson Prentice Hall, Upper Saddle River, New Jersey, pp: 318-320.

22. Piczak, K., A. Lesniewicz and W. Zyrnicki, 2003. Metal concentrations in deciduous tree leaves from urban areas in Poland. Environ. Monitoring Assess., 86 (3): 273-287.

23. Mankovska, B., 1998. The chemical composition of spruce and beech foliage as an environmental indicator in Slovakia. Chemosphere, 36 (4-5): 949953.

24. Elowson, S. and L. Rytter, 1988. Dynamics of leaf minerals, leaf area and biomass from hardwoods intensively grown on a peat bog. Trees-Structure and Function, 2 (2): 84-91.

25. Young, H.E. and V.P. Guinn, 1966. Chemical elements in complete mature trees of seven species in Maine. Tappi, 49 (5): 190-197.

26. Reeves, R.D. and A.J.M. Baker, 2000. Metalaccumulating plants. In: Raskin, I. and B.D. Ensley (Eds.). Phytoremediation of Toxic Metals: Using Plants to Clean Up the Environment. John Wiley and Sons Inc., New York, New York, pp: 193-230.

27. Long, R.P., S.B. Horsley and P.R. Lilja, 1997. Impact of forest liming on growth and crown vigor of sugar maple and associated hardwoods. Can. J. Forest Res., 27 (10): 1560-1573.

28. Lin, Z.Q., P.H. Schuepp, R.S. Schemenauer and G.G. Kennedy, 1995. Trace metal contamination in and on balsam fir (Abies balsamea) foliage in southern Quebec, Canada. Water, Air and Soil Pollution, 81 (1-2): 175-191.

29. Kolb, T.E. and L.H. McCormick, 1993. Etiology of sugar maple decline in four Pennsylvania stands. Can. J. Forest Res., 23 (11): 2395-2402.

30. Kazda, M. and L. Zvacek, 1989. Aluminum and manganese and their relation to calcium in soil solution and needles in three Norway spruce (Picea abies) stands of Upper Austria. Plant and Soil, 114 (2): 257-267.

31. Hoyle, M.C., 1972. Manganese toxicity in yellow birch (Betula alleghaniensis) seedlings. Plant and Soil, 37 (1): 229-232. 
32. McColl, J.G., 1981. Trace elements in the hydrologic cycle of a forest ecosystem. Plant and Soil, 62 (3): 337-349.

33. Brotherson, J.D. and S.T. Osayande, 1980. Mineral concentrations in true mountain mahogany and Utah juniper and in associated soils. J. Range Manage., 33 (3): 182-185.

34. Morrison, I.K. and G.D. Hogan, 1986. Trace element distribution within the tree phytomass and forest floor of a tolerant hardwood stand, Algoma, Ontario. Water, Air and Soil Pollution, 31: 493-500.

35. Schmitt, M.D.C., M.M. Czapowskyj, L.O. Safford and A.L. Leaf, 1981. Biomass and element uptake in fertilized and unfertilized Betula papyrifera and Populus grandidentata. Plant and Soil, 60 (1): 111-121.

36. Wittwer, R.F., A.L. Leaf and D.H. Bickelhaupt, 1975. Biomass and chemical composition of fertilized and/or irrigated Pinus resinosa plantations. Plant and Soil, 42 (3): 629-651.

37. Saarela, K.-E., L. Harju, J. Rajander, J.-O. Lill, S.-J. Heselius, A. Lindroos and K. Mattsson, 2005. Elemental analyses of pine bark and wood in an environmental study. Sci. Total Environ., 343 (1-3): 231-241.

38. Basham, H.G. and E.B. Cowling, 1976. Distribution and essential elements in forest trees and their role in wood deterioration. In: Becker, G. and W. Liese (Eds.). Organismen und holz. Duncker and Humblor, Berlin, Germany, pp: 156-165.

39. Miller, R.B., 1999. Structure of Wood. In: Wood handbook-Wood as an engineering material. United States Department of Agriculture, Forest Service, Forest Products Laboratory, Madison, Wisconsin, pp: 21-24.

40. Heinrichs, H. and R. Mayer. 1980. The role of forest vegetation in the biogeochemical cycle of heavy metals. J. Environ. Quality, 9 (1): 111-118.

41. Vogt, K.A., R. Dahlgren, F. Ugolini, D. Zabowski, E.E. Moore and R. Zasoski, 1987. Aluminum, $\mathrm{Fe}, \mathrm{Ca}, \mathrm{Mg}, \mathrm{K}, \mathrm{Mn}, \mathrm{Cu}, \mathrm{Zn}$ and $\mathrm{P}$ in above- and belowground biomass. I. Abies amabilis and Tsuga mertensiana. Biogeochemistry, 4 (3): 277294.
42. Rodriguez-Barrueco, C., C. Miguel and P. Subramaniam, 1984. Seasonal fluctuations of the mineral concentration of alder (Alnus glutinosa (L.) Gaertn.) from the field. Plant and Soil, 78 (1-2): 201-208.

43. Turner, J., D.W. Cole and S.P. Gessel, 1976. Mineral nutrient accumulation and cycling in a stand of red alder (Alnus rubra). J. Ecol., 64 (3): 965-974.

44. Mertens, J., P. Vervaeke, E. Meers and F.M.G. Tack, 2006. Seasonal changes of metals in willow (Salix sp.) stands for phytoremediation on dredged sediment. Environ. Sci. Technol., 40 (6): 1962-1968.

45. Oleksyn, J., R. Zytkowiak, P.B. Reich, M.G. Tjoelker and P. Karolewski, 2000. Ontogenetic patterns of leaf $\mathrm{CO}_{2}$ exchange, morphology and chemistry in Betula pendula trees. Trees-Structure and Function, 14 (5): 271-281.

46. Moorhead, K.K. and J.V. McArthur, 1996. Spatial and temporal patterns of nutrient concentrations in foliage of riparian species. Am. Midland Naturalist, 136 (1): 29-41.

47. Lea, R., W.C. Tierson, D.H. Bickelhaupt and A.L. Leaf, 1979. Stand treatment and sampling time of hardwood foliage. II. Micro-element analysis. Plant and Soil, 51 (4): 535-550.

48. Laureysens, I., R. Blust, L. De Temmerman, C. Lemmens and R. Ceulemans, 2004. Clonal variation in heavy metal accumulation and biomass production in a poplar coppice culture: I. Seasonal variation in leaf, wood and bark concentrations. Environ. Pollution, 131 (3): 485-494.

49. Zottl, H.W., 1985. Heavy metal levels and cycling in forest ecosystems. Cellular and Molecular Life Sci., 41 (9): 1104-1113. 